\title{
FYZICKÉ ZKLIDŇOVÁNÍ DOPRAVY NA VYBRANÝCH MÍSTNÍCH KOMUNIKACÍCH V HLAVNIIM MĚSTĚ PRAZE
}

\section{PHYSICAL TRAFFIC CALMING ON SELECTED LOCAL ROADS IN THE CAPITAL CITY OF PRAGUE}

Zdeňka Stojaspalová1,*

\begin{abstract}
Abstrakt Př́spěvek se zabývá problematikou zklidňování dopravy na vybraných úsecích místních komunikací, které se nacházejí na území hl. m. Prahy. Jedná se o úseky s celoročně sledovanou intenzitou dopravy. Na daných úsecích proběhlo místní šetření a analýza vybraných atributů (druh fyzického zklidňovacího opatření, umístění, intenzita dopravy apod.). V př́spěvku jsou dále ověrovány hypotézy, zda je umist'ování vybraných fyzických zklidňovacích prvků na daných úsecích konzistentní (dle typu opatření a dle príčiny instalace) a zda je jejich počet závislý na hodnotě intenzity dopravy nebo délce úseku. Předmětné hypotézy závislosti opatření na délce úseku nebo intenzitě byly vyvráceny, ale byla upřesněna možnost rozšíření množství dat a jejich analýzy k nalezení komplexnějších závislostí.
\end{abstract}

Klíčová slova intenzita dopravy, zklidňovací opatření, zklidňování dopravy

Summary The paper deals with the issue of traffic calming on selected sections of local roads, which are located in the capital city of Prague. These are sections with monitored traffic intensity. On the given sections, a local survey and analysis of selected attributes (type of physical traffic calming measure, location, traffic intensity, etc.) took place. The paper also verifies hypotheses whether the location of selected physical calming elements on given sections is consistent (according to the type of measure and the cause of need) and whether their number depends on the value of traffic intensity or length of the section. The hypotheses of the dependence of the measure on the length of the section or the intensity were refuted, but the way to a possible expansion of the amount of data and their analysis to find more complex dependencies was outlined.

Keywords $\quad$ traffic calming, traffic calming measures, traffic intensity

\section{1 ÚVOD}

Místní komunikaci v libovolném intravilánu nedefinují např. pouze 2 jízdní pruhy s vyznačeným vodorovným dopravním značením (dále jen VDZ) a svislým dopravním značením (dále jen SDZ). Místní komunikace jsou často využívány jak motorovou, tak i nemotorovou dopravou a proto jsou zpravidla v jejich blízkosti také vedeny stezky pro cyklisty a pro pěší. Současně je důležité i vedení pěší/cyklo

\footnotetext{
${ }^{1}$ Univerzita Pardubice, Dopravní fakulta Jana Pernera, Katedra technologie a řízení dopravy, Studentská 95, 53210 Pardubice, Česká republika

*korespondenční autor, tel.: +420 774989 443, e-mail: zdenka.stojaspalova@student.upce.cz
} 
dopravy přes tyto komunikace (např. přechody pro chodce a jejich vybavení apod.). Nutné je zohlednit také časté umístění zastávek veřejné hromadné dopravy nebo i objektů v okolí - různá školní, zdravotní a kulturní zařízení, obytné budovy apod. Současně, jak už je z názvu patrné, tak nalezneme místní komunikace v intravilánu, kde je oproti extravilánu nižší nejvyšší dovolená rychlost (zpravidla 50 km/h).

Ovšem pravidlo dodržování nejvyšší dovolené rychlosti (nejenom vintravilánu) není vždy řidiči adekvátně respektováno. Ve statistikách z dat získaných od Policie České republiky (Policie ČR, 2021) je nedodržení nejvyšší dovolené rychlosti pravidelně v 4 nejčastějších příčinách dopravních nehod.

Z tohoto i dalších důvodů (obecně zvýšení bezpečnosti motorových i nemotorových účastníků provozu; snížením rychlosti je snižována hluková zátěž; snížení intenzity dopravy; zvýšení samovysvětlitelnosti pozemních komunikací; zvýšení kvality života obyvatel apod.) je využívána realizace různých opatření zklidňování dopravy. (CDV, 2020)

Příspěvek je zaměřen na analýzu vybraných úseků místních komunikací na území hl. m. Prahy. Na úsecích byl autorkou během první poloviny dubna 2021 zjišt'ován výskyt fyzických zklidňovacích prvků a byly ověřovány hypotézy, zda je tento výskyt ovlivněn délkou úseku a naměřenou intenzitou dopravy. Současně byl kladen důraz na to, zda je výskyt zklidňovacích prvků fyzických na vybraných úsecích konzistentní (tzn. použití jednoho typu prvku na konkrétním úseku, příp. stejná př́íčina nutnosti instalace i různých prvků). Přínosem zkoumání této problematiky je nalezení možných závislostí, co vše může a nemusí ovlivňovat volbu druhu a počet zklidňovacích opatření na konkrétním typu úseku místní komunikace.

\section{ZKLIDŇOVÁNÍ DOPRAVY NA MÍSTNÍCH KOMUNIKACÍCH}

Pravidla a doporučení pro výběr vhodných zklidňovacích opatření na místních komunikacích jsou uvedeny v technických podmínkách: TP 132 - Zásady návrhu dopravního zklidňování na místních komunikacích (MD ČR, 2000), příp. v technických podmínkách přímo pro specifický druh zklidňovacího opatření: TP 85 - Zpomalovací prahy (MD ČR, 2013).

Opatření pro zklidňování dopravy se často už stává součástí nových projektů, ale jsou také využíána při rekonstrukci/renovaci mezikřižovatkových úseků nebo křižovatek na stávajících místních komunikacích. Opatření, resp. prvky se rozdělují podle jejich povahy na psychologické a fyzické, př́íp. fyzickopsychologické. Při realizaci je časté i využívání kombinace fyzických a psychologických prvků, kdy při správné kombinaci pro danou lokalitu může nastat žádoucí synergický efekt.

\subsection{Psychologické zklidňování dopravy}

Psychologické prvky pro zklidňování dopravy velmi často slouží k upozornění na místa, kde jsou řidiči fyzicky donuceni např. ke snížení rychlosti nebo směru jízdy apod.

Mezi psychologické prvky patří:

- SDZ (např. př́imo snížení nejvyšší dovolené rychlosti, ale také opakování SDZ vícekrát za sebou apod.),

- vytvoření dojmu kontroly (umělá figurína policisty, informační rychlostní radar atd.),

- VDZ (klikatá čára, optická brzda atd.)

- odlišná barva nebo kryt vozovky apod.

\subsection{Fyzické zklidňování dopravy}

Mezi prvky pro fyzické zklidňování dopravy patří:

- zpomalovací prahy,

- zvýšené plochy (např. u přechodu pro chodce nebo v křižovatce), 
- dopravní šikana (vysazené chodníkové plochy, dělicí ostrůvky, posun obrub, parkování podélné apod.),

- zúžení vozovky.

V př́spěvku je kladen důraz pouze na fyzické prvky zklidňování dopravy, jelikož ty fakticky řidiče vozidel svým provedením donutí ke změně rychlosti při jízdě.

\section{VÝZKUMNÝ PROBLÉM}

Autorkou byly formulovány následující hypotézy, které byly potvrzeny nebo vyvráceny v částech 5.1 až 5.3:

- délka úseku ovlivňuje počet fyzických zklidňovacích opatření,

- intenzita dopravy ovlivňuje počet nalezených zklidňovacích opatření,

- vrámci jednoho úseku jsou instalované fyzické zklidňovací prvky pouze stejného typu (zachování konzistentnosti).

\section{VÝBĚR MÍSTNÍCH KOMUNIKACÍ}

Kanalýze v př́spěvku byly autorkou vybrány místní komunikace podle předem určených pravidel uvedených v částech 4.1. a 4.2. Bylo identifikováno celkem 16 úseků pražských místních komunikací splňujících vybraná kritéria. Souhrnná délka úseků je cca 24 km (Mapy.cz, 2020) v jednom směru. Pro následné porovnání a analýzu byly úseky cíleně lokalizovány v různých částech hlavního města (viz obr. 1), číslice na mapě odpovídá ID úseku uvedenému v tab. 1.

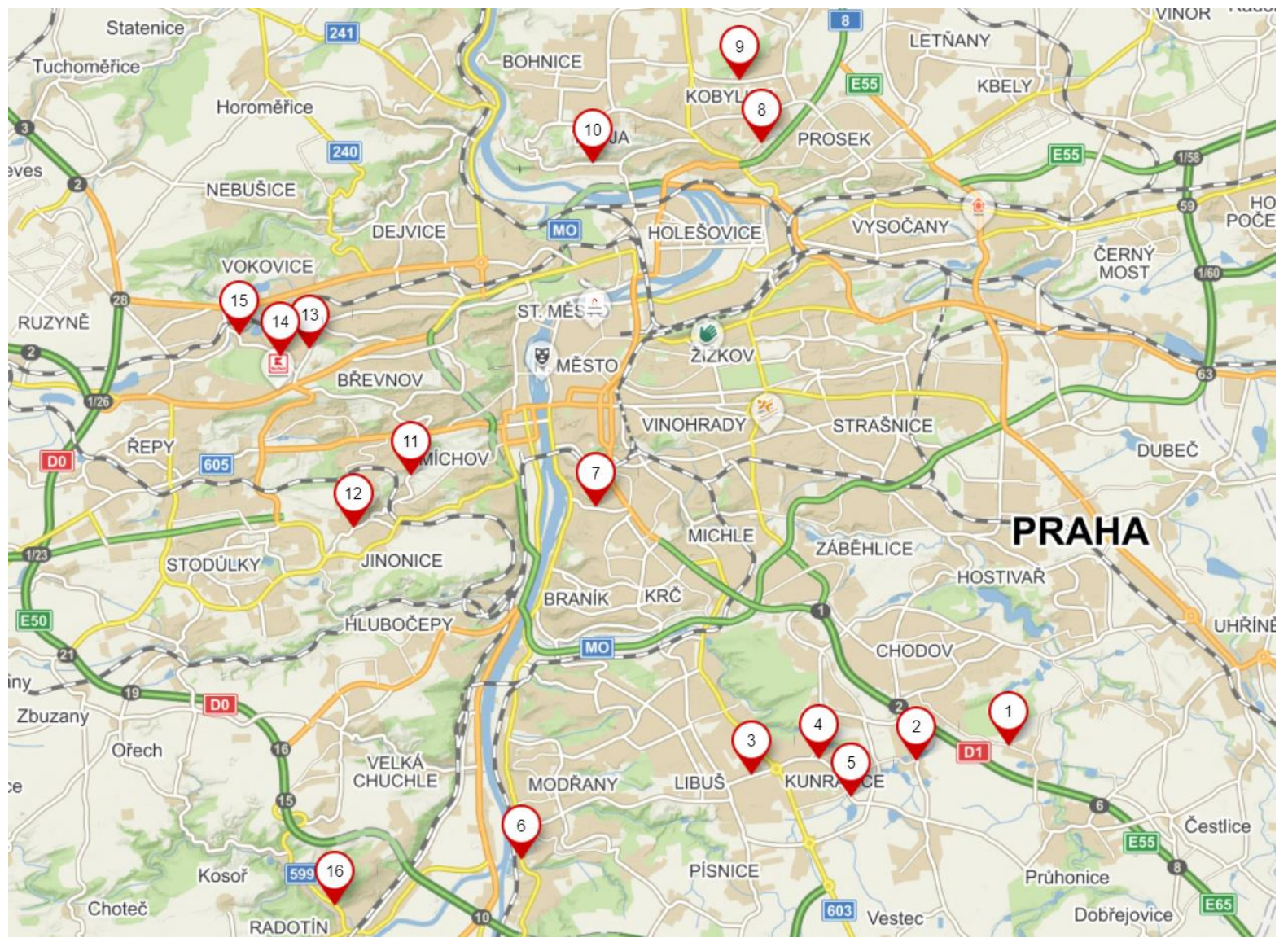

Obr. 1 Lokace úseků; zdroj: Mapy.cz 


\subsection{Výběr lokalit}

Byly vybrány takové lokality, které jsou každoročně sledovány Technickou správou komunikací hl. m. Prahy, a.s. (TSK, 2021) a jsou u nich proto dostupné některé dopravně-inženýrské charakteristiky, např.:

- intenzita dopravy na vybraném profilu [vozidla/24 h] ve skladbě všechna vozidla / vozidla nad 3,5 tuny,

- průměrná rychlost vozidel na profilu $[\mathrm{km} / \mathrm{h}]$ pro všechna vozidla,

- podíl nočních jízd (22-06 h) uvedený pro všechna vozidla.

Nicméně je nutné podotknout, že vybrané charakteristiky mohou být i omezující pro další zkoumání. Intenzita je uváděna pro daný profil (tzn. součet pro oba směry), není také možné např. sledovat pouze špičkovou hodinu apod. Stejně tak charakteristika průměrná rychlost je pouze uvedena pro celý úsek (délka úseků je odlišná od desítek metrů po stovky metrů až jednotky kilometrů), tudíž může být vliv např. 1 fyzického zklidňovacího opatření na delším úseku těžko rozpoznatelný.

\subsection{Výběr konkrétních úseků}

Ve vybrané lokalitě byly konkrétněji selektovány úseky místních komunikací na základě dalších parametrů tak, aby bylo možné je při analýze porovnávat mezi sebou a dále s nimi pracovat, př́padně v budoucnu vybrat další obdobné úseky i z jiných měst. Cílem bylo vybrat takové úseky, které by se daly považovat za téměř shodné svým uspořádáním, funkcí, organizací dopravy apod. Jako variabilní byla uvažována hodnota intenzity dopravy a délka úseku. Následně byl na úsecích zjišt'ován počet a provedení zklidňovacích fyzických opatření.

Vybrané úseky mají společné tyto charakteristiky:

- obousměrný provoz,

- uspořádání 1+1 jízdní pruh (pro každý směr 1 jízdní pruh),

- směrově nerozdělené,

- bez tramvajové trati,

- zástavba kolem místní komunikace je složena z rodinných domů, př́p. bytových domů a k nim přilehlé občanské vybavenosti (škola, školka, zastávka veřejné hromadné dopravy),

- provoz autobusů městské hromadné dopravy,

- možnost podélného parkování.

Vybrané místní komunikace (resp. jejich úseky) jsou patrné z tab. 1, kde je uveden název úseku a jeho délka. Současně jsou v tab. 1 uvedeny uzly na začátku a konci úseku pro přesnější lokalizaci.

Tab. 1 Vybrané úseky a jejich délka; zdroj: autorka na podkladě (TSK, 2019)

\begin{tabular}{llrrr}
\hline ID úseku & Název úseku & Délka [m] & Uzel od & Uzel do \\
\hline 1 & Ke Kateřinkám & 2725 & 4110 & 4109 \\
2 & K Hrnčírum & 2100 & 4084 & 4079 \\
3 & Dobronická & 1025 & 4062 & 4038 \\
4 & K Libuši & 700 & 4038 & 4270 \\
5 & K Šeberáku & 2200 & 4270 & 4082 \\
6 & Komořanská & 1500 & 4051 & 4050 \\
7 & Na Dolinách & 1200 & 4023 & 4041 \\
8 & Davídkova & 950 & 8048 & 8040 \\
9 & Žernosecká & 1800 & 8031 & 8042 \\
10 & Trojská & 1560 & 7031 & 7030 \\
11 & Jinonická & 1610 & 5056 & 5057
\end{tabular}




\begin{tabular}{llrrr} 
ID úseku & Název úseku & Délka [m] & Uzel od & Uzel do \\
\hline 13 & Ankarská & 1110 & 6031 & 6026 \\
14 & Na Vypichu & 660 & 6028 & 6031 \\
15 & Libocká & 1120 & 6028 & 6029 \\
16 & K Cementárně & 2120 & 5083 & 5079 \\
\hline
\end{tabular}

\section{ANALÝZA VYBRANÝCH ÚSEKŮ}

Sběr analyzovaných dat (počet a druh zklidňovacích prvků) provedla autorka na úsecích uvedených v tab. 1 ve dnech 1. 4. - 4. 4. 2021. Meteorologické podmínky nebyly ve dnech šetření nijak zhoršeny (vozovka bez souvislé sněhové vrstvy), proto nehrozilo, že by mohlo dojít např. k přehlédnutí některého fyzického zklidňovacího prvku.

Na vybraných 16 úsecích místních komunikací bylo identifikováno celkem 25 fyzických zklidňovacích prvků. Na všechny prvky je adekvátně upozorněno pomocí SDZ, příp. VDZ dle TP 65 - Zásady pro dopravní značení na pozemních komunikacích (MD ČR, 2013).

Lokalizovaná opatření jsou bez výjimky umístěna v místě přechodů pro chodce. Žádné fyzické opatření není umístěno např. před křižovatkou, autobusovou zastávkou nebo v místě jiného nebezpečí. V 11 př́ipadech je také snížena nejvyšší dovolená rychlost na 30, resp. $20 \mathrm{~km} / \mathrm{h}$. Jednalo se o místa, kde je v blízkosti přechodů pro chodce základní nebo mateřská škola.

Skladba a četnosti analyzovaných opatření jsou patrné z obr. 2., kde je zřejmé, že nejčastějším fyzickým opatřením pro zklidnění dopravy na vybraných úsecích je příčný práh (dlouhé i krátké provedení).

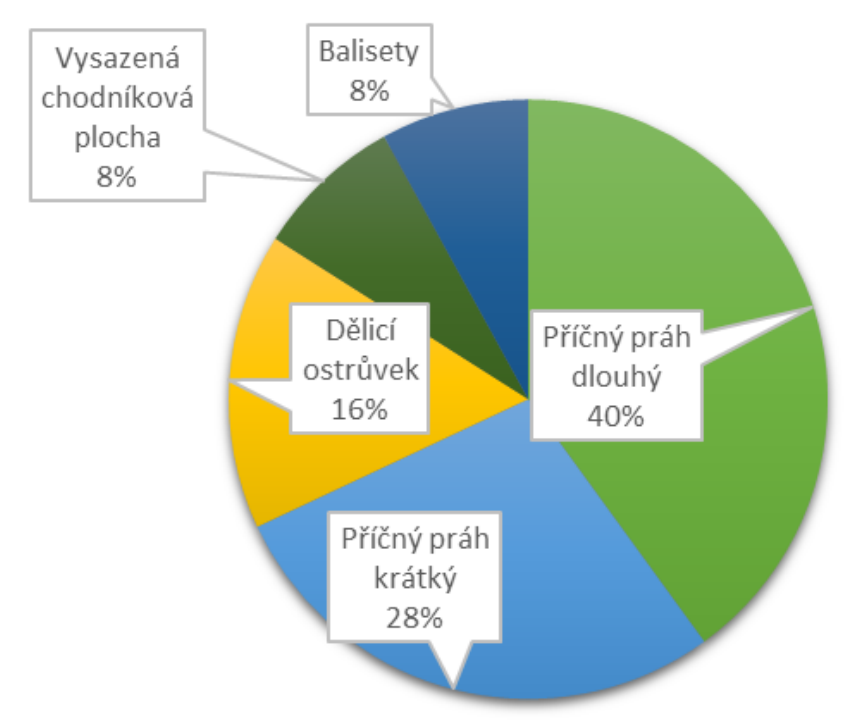

Obr. 2 Zastoupení jednotlivých opatření; zdroj: autorka

Dlouhým prahem se rozumí vyvýšená vozovka v místě přechodu pro chodce (viz obr. 3). V př́padě krátkého prahu se jedná pouze o vyvýšení před a za přechodem pro chodce.

Pokud je zklidňující opatření pojmenováno jako „balisety“, jedná se o umístění dopravního zařízení baliseta ve středu přechodu pro chodce. Balisety v takovém případě simulují dělicí ostrůvek. 


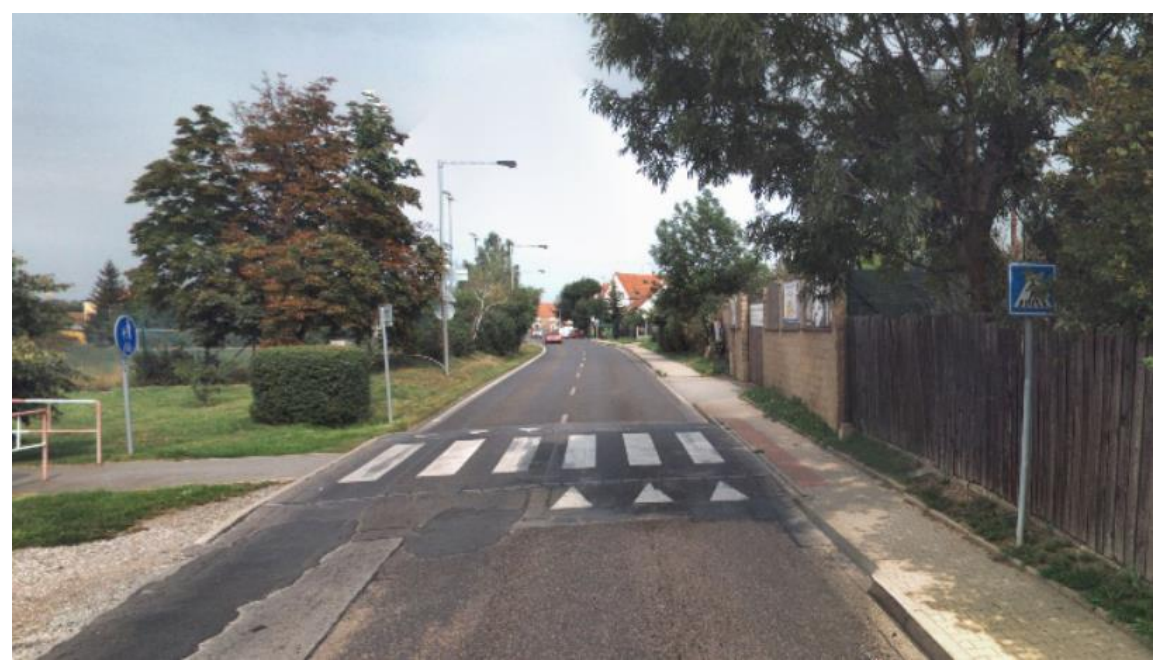

Obr. 3 Dlouhý příčný práh, ul. K Hrnčířo̊m; zdroj: Mapy.cz

Podrobnější analýza a ověření hypotéz, zda souvisí délka úseku a intenzita dopravy s počtem a druhem zklidňovacích opatření jsou uvedeny samostatně v částech 5.1. a 5.2.

Pro podrobnější analýzu byla sestavena tab. 2., kde je vždy uvedena intenzita dopravy v úseku (hodnota pro profil, tzn. obousměrně). Hodnota intenzity dopravy je vyjádřena jako součet jízd všech vozidel (včetně těch nad 3,5 t) za 24 h. Hodnoty intenzit jsou z roku 2019, tzn. bez vlivu pandemie koronaviru CV-19. V tab. 2 jsou uvedeny také počty jednotlivých zklidňujících opatření. Červeně jsou ve sloupci ID zvýrazněny tři řádky, kde nebyl v rámci šetření nalezen ani jeden fyzický prvek pro zklidňování dopravy.

Tab. 2 Vybrané úseky a zklidňovací prvky; zdroj: autorka

\begin{tabular}{llrrrrrrr}
\hline ID & Název úseku & $\begin{array}{c}\text { Délka } \\
\text { [m] }\end{array}$ & $\begin{array}{c}\text { Intenzita } \\
\text { [voz/24h] }\end{array}$ & $\begin{array}{c}\text { Příčný } \\
\text { dlouhý } \\
\text { práh }\end{array}$ & $\begin{array}{c}\text { Př́íný } \\
\text { krátký } \\
\text { práh }\end{array}$ & $\begin{array}{c}\text { Balisety } \\
\text { ostrůvek }\end{array}$ & $\begin{array}{c}\text { Dělić } \\
\text { chodníková } \\
\text { plocha }\end{array}$ \\
\hline 1 & Ke Kateřinkám & 2725 & 2900 & 1 & 2 & 0 & 0 & 0 \\
2 & K Hrnčír̆um & 2100 & 12800 & 3 & 0 & 0 & 0 & 0 \\
3 & Dobronická & 1025 & 12200 & 0 & 0 & 1 & 0 & 0 \\
4 & K Libuši & 700 & 17000 & 2 & 0 & 0 & 0 & 0 \\
5 & K Šeberáku & 2200 & 6700 & 1 & 0 & 0 & 0 & 0 \\
6 & Komořanská & 1500 & 18000 & 0 & 0 & 0 & 1 & 1 \\
7 & Na Dolinách & 1200 & 13000 & 1 & 0 & 0 & 1 & 0 \\
8 & Davídkova & 950 & 11000 & 0 & 0 & 0 & 0 & 0 \\
9 & Žernosecká & 1800 & 11700 & 0 & 0 & 0 & 0 & 0 \\
10 & Trojská & 1560 & 12500 & 0 & 1 & 1 & 0 & 0 \\
11 & Jinonická & 1610 & 10000 & 0 & 0 & 0 & 1 & 1 \\
12 & Karlštejnská & 780 & 19000 & 0 & 2 & 0 & 0 & 0 \\
13 & Ankarská & 1110 & 16200 & 0 & 0 & 0 & 1 & 0 \\
14 & Na Vypichu & 660 & 9300 & 0 & 0 & 0 & 0 & 0 \\
15 & Libocká & 1120 & 16800 & 1 & 0 & 0 & 0 & 0 \\
16 & K Cementárně & 2120 & 9000 & 1 & 2 & 0 & 0 & 0 \\
\hline
\end{tabular}

\subsection{Vztah délky úseku a nalezených zklidňovacích opatření}

Data, ze kterých bylo vycházeno v rámci ověření hypotézy, zda počet nalezených opatření závisí na délce úseku, jsou zobrazena v tab. 2 . 
Na obr. 4 byly pro přehlednost úseky seřazeny dle své délky od nejdelšího po nejkratší (vodorovná osa). Na svislé ose je vynesen počet nalezených fyzických zklidňujících opatření.

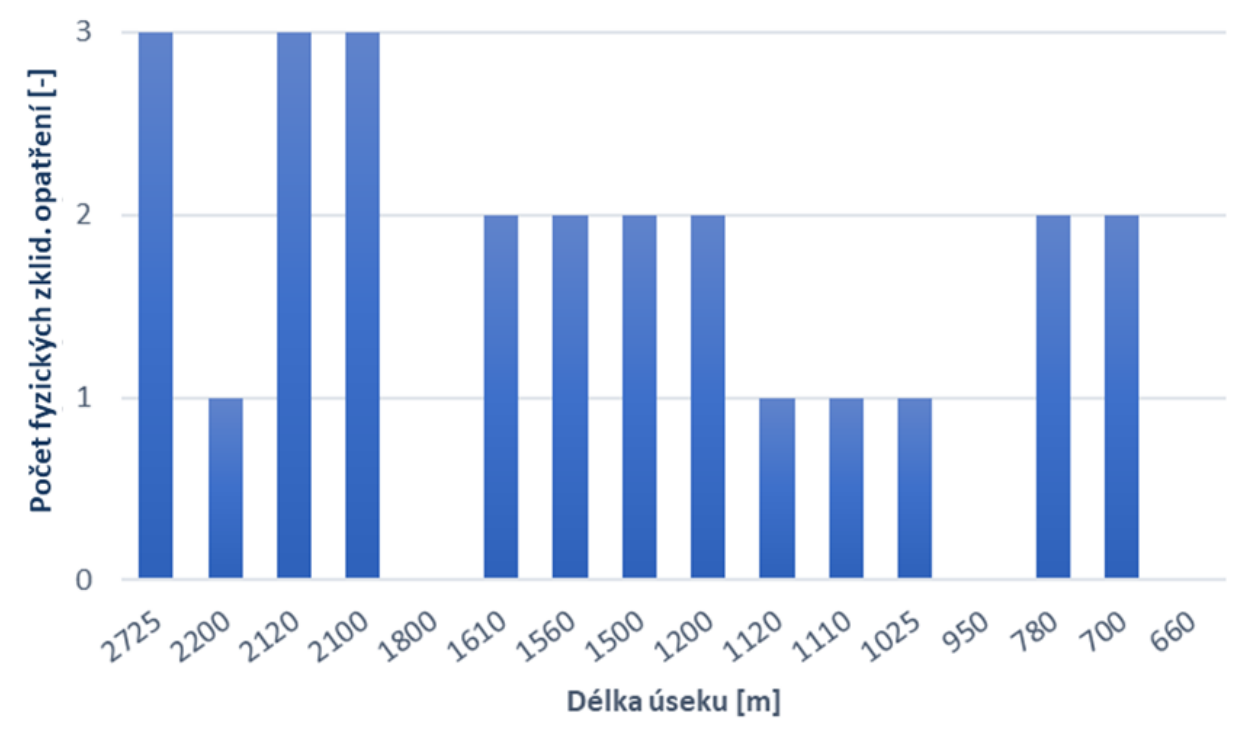

Obr. 4 Délka úseku a počet opatření; zdroj: autorka

Z obr. 4 je patrné, že sice jsou zleva řazeny nejdelší úseky, kdy u 3 nejdelších úseků ze 4 byly nalezeny 3 zklidňující prvky, nicméně u 1 úseku je to pouze prvek jeden. Následuje úsek dlouhý $1800 \mathrm{~m}$, kde nebyl identifikován ani jeden zklidňující prvek.

Ani při další analýze grafu z obr. 4 (například při postupování naopak od nejkratších úseků) není patrný vzorec, který by mohl obecně charakterizovat př́padnou závislost počtu fyzických zklidňovacích prvků na délce úseku.

Je ale potřebné podotknout, že délka úseku nemusí být jediným kritériem pro počet dopravnězklidňujících opatření. Detailněji proto byly ještě analyzovány:

- 3 nejdelší úseky, kde jsou shodně umístěna 3 zklidňovací opatření (tzn. úseky Ke Kateřinkám, K Hrnčírưum a K Cementárně),

- úsek, který je kvůli délce na pomyslném 2. místě (tzn. úsek K Šeberáku), kde je pouze 1 opatření.

Z návazné analýzy vyplývá, že tento rozdíl v počtu zklidňujících prvků může být způsoben občanskou vybaveností v okolí úseku. Kolem místní komunikace K Šeberáku (1 opatření) se nachází pouze rodinné domy.

V okolí trojice zmíněných úseků se 3 opatřeními se ale současně nachází obchody, restaurace, mateřská škola, což může generovat vyšší intenzitu pěší dopravy, resp. potřebu snížení rychlosti projíždějících vozidel. Tento předpoklad (spojitost s občanskou vybaveností) by i vysvětloval, proč jsou úseky Davídkova (délka $950 \mathrm{~m}$ ) a Na Vypichu (délka $660 \mathrm{~m}$ ) zcela bez zklidňovacích prvků - podél pozemní komunikace jsou pouze rodinné domy a jedná se o krátké úseky.

\subsection{Vztah intenzity dopravy a nalezených zklidňovacích opatření}

Data, ze kterých bylo vycházeno v rámci ověření hypotézy, zda počet nalezených opatření závisí na intenzitě dopravy, jsou zobrazena v tab. 2 .

Na obr. 5 byly pro přehlednost úseky seřazeny dle intenzity zleva od nejvytíženějšího (vodorovná osa). Na svislé ose je vynesen počet nalezených fyzických zklidňujících opatření. 


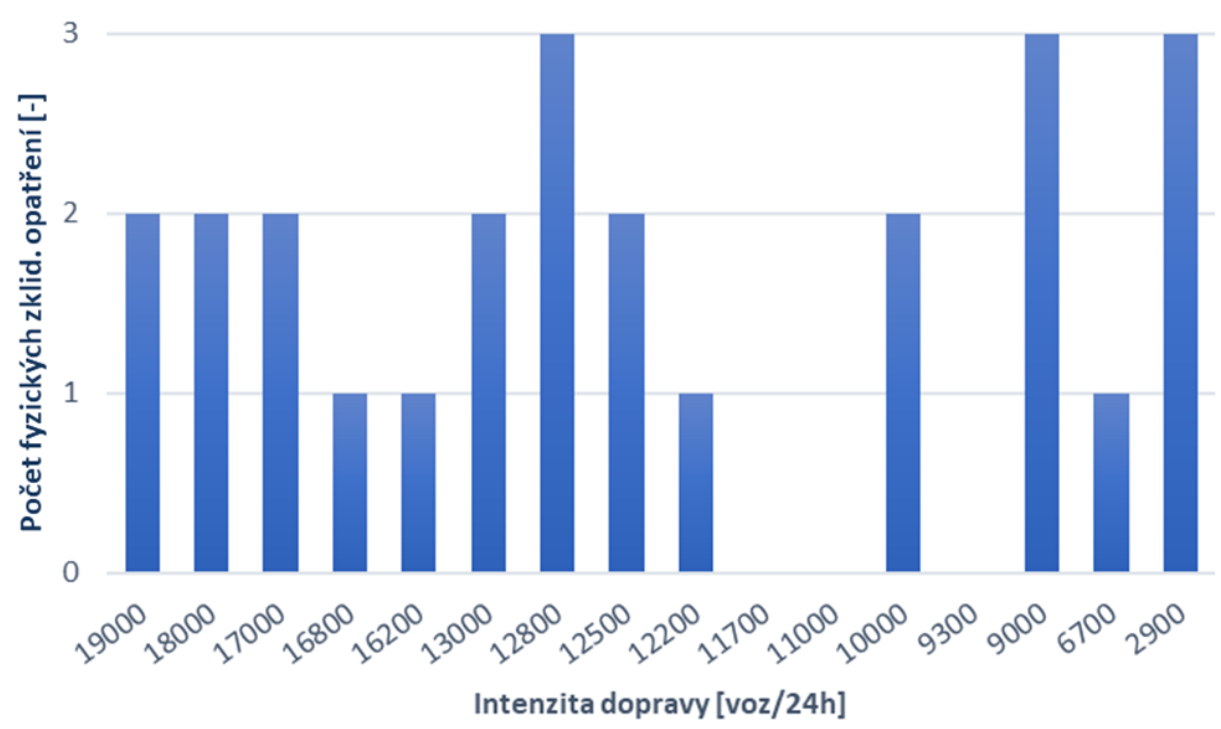

Obr. 5 Intenzita dopravy a počet opatření; zdroj: autorka

Z analýzy obr. 5 je patrné, že na vybraných úsecích s intenzitou vyšší než 12000 voz/24h dochází k instalaci fyzických zklidňujících prvků, nejen pouze psychologických. Při hodnotách nižších než 12000 voz/24 h toto pravidlo na vybraných úsecích obecně neplatí. Ovšem úseky s intenzitou 11000 a 11700 voz/24 h (kde není ani jeden fyzický prvek) se oba shodně nachází v městské části Kobylisy. Je tedy možné, že v této části je preferováno pouze psychologické zklidňování dopravy.

Opět (stejně jako v části 4.1.) nelze nalézt jednoznačnou klesající nebo naopak rostoucí tendenci v umist'ování fyzických zklidňovacích prvků v závislosti na intenzitě dopravy. U úseků, kde je nižší intenzita a stejně na nich jsou instalovány fyzické zklidňovací prvky (K Šeberáku - 1 prvek; Ke Kateřinkám - 3 prvky) ještě může hrát roli i to, že se nachází na okraji obce a je tak tedy řidičům zdůrazněn přechod z extravilánu do intravilánu - nicméně pro ověření tohoto tvrzení by bylo nutné mít k dispozici další data (např. vzdálenost úseku od centra/konce obce, směrové vedení komunikace před/za úsekem, rychlost projíždějících vozidel atd.).

\subsection{Konzistentnost nalezených zklidňovacích opatření}

Z pohledu konzistentnosti identifikovaných zklidňovacích opatření pro jednotlivé úseky lze konstatovat, že u 9 úseků ze 13 (3 úseky byly zcela bez fyzických zklidňovacích prvků) je možné volbu považovat za konsistentní. Na těchto 9 úsecích se nachází pouze jeden prvek nebo více prvků, které jsou ale stejného druhu (příčný práh dlouhý nebo krátký, případně samostatné balisety nebo dělicí ostrůvek). Pouze v př́padě 4 úseků se jedná o kombinaci dvou neshodných prvků:

- dělicí ostrůvek \& prríčný práh dlouhý - 1x,

- dělicí ostrůvek \& vysazená chodníková plocha - 2x,

- příčný práh krátký \& balisety - 1x.

Jelikož jsou všechna zklidňovací opatření umíst'ována u přechodů pro chodce (tzn. upozornění na stejné místo), z pohledu autorky je žádoucí, aby vždy na jednom úseku byla opatření stejného typu - tzn., aby se předcházelo tomu, že bude např. u každého přechodu pro chodce vždy jiné opatření. Mohlo by poté u řidičů docházet k větší koncentraci na vhodné projetí/přejetí daného prvku, než na sledování reálné dopravní situace (např. děti čekající na přednost na přechodu pro chodce).

Při detailnější analýze zhruba poloviny úseků ještě vyšlo najevo, že přechody pro chodce se na jednotlivých úsecích objevují vícekrát, že ne každý přechod pro chodce je doplněn o fyzický prvek zklidňování dopravy. Privilegované přechody byly zejména přechody pro chodce v blízkosti základních 
a mateřských škol. Tento fakt, se může jevit na jednu stranu v pořádku, že je na některé přechody pro chodce více upozorněno, nicméně potom by to v některých řidičích mohlo vyvolat otázku, zda jsou některé přechody méně důležité než jiné.

\section{ZÁVĚR}

Místní komunikace mají v dopravní síti nezastupitelnou roli. Často ovšem řidiči nejen motorových vozidel nerespektují nastavená pravidla (např. nedodržování nejvyšší dovolené rychlosti atd.). I z těchto důvodů dochází ke zklidňování dopravy. Pro příspěvek byly vybrány dle specifických kritérií místní komunikace $\mathrm{z}$ hl. m. Prahy a následně byla provedena analýza týkající se problematiky zklidňování dopravy (resp. fyzických opatření pro zklidňování dopravy).

Nebyla potvrzena ani jedna hypotéza, že by počet zklidňovacích prvků závisel na délce vybraných úseků nebo na intenzitě dopravy na těchto úsecích. Proto nelze doporučit např. vhodné řešení pro zklidnění dopravy na jiném obdobném úseku. $V$ otázce konzistentnosti volby a umístění zklidňovacích prvků lze konstatovat, že ve většině př́padů ( 9 z 13) je vždy na jednom úseku umist'ován pouze jeden druh zklidňovacího prvku. U ostatních dochází ke kombinaci dvou druhů.

V návaznosti na nepotvrzené hypotézy týkající se závislosti opatření na intenzitě dopravy, resp. na délce úseku by bylo možné a vhodné v budoucnu analýzu vybraných úseků ještě rozšíŕit. Rozšíření by mohlo obsahovat další obdobné úseky (např. i z jiných měst). Také zohlednit časově a zdrojově náročnější analýzu, resp. př́stup, kdy budou brány v potaz i psychologické prvky vkombinaci s uvedenými fyzickými. Současně by bylo vhodné více analyzovat i okolí vybraných úseků a např. intenzitu pěší dopravy apod., př́ip. i jejich vzdálenost od centra/konce obce, směrové/výškové vedení apod.

\section{Literatura}

Centrum dopravního výzkumu. @ 2020. Organizace dopravy - zklidňování [online]. Dostupné z: https://www.cdv.cz/file/organizace-dopravy-zklidnovani// [cit. 2021-04-02].

Mapy.cz. (C) 2020. [Online]. Dostupné z: https://www.mapy.cz [cit. 2021-04-10].

Ministerstvo dopravy ČR. 2000. TP 132 Zásady návrhu dopravního zklidňování na místních komunikacích. Praha.

Ministerstvo dopravy ČR. 2013. TP 65 Zásady pro dopravní značení na pozemních komunikacích. Praha.

Ministerstvo dopravy ČR. 2013. TP 85 Zpomalovací prahy. Praha.

Policie ČR. (C) 2021. Statistika nehodovosti. [Online]. Dostupné z:

https://www.policie.cz/clanek/statistika-nehodovosti-900835.aspx?q=Y2hudW09MQ\%3d\%3d

[cit.: 11. 04. 2020].

TSK. (C) 2019. Praha - Sledovaná Komunikační sít'. [Online]. Dostupné z: https://www.tsk-

praha.cz/wps/wcm/connect/www.tsk-praha.cz20642/2a157eef-ef0e-4227-b991-

1c60a8ede618/Sledovana komunikacni sit pro dopravni scitani - cela Praha 2019.pdf?MOD=AJPERES\&id=1585662467842 [cit. 2021-04-02].

TSK. (C) 2021. Intenzity dopravy, podíly noci a průměrné jízdní rychlosti [online]. Dostupné z:

https://www.tsk-praha.cz/wps/portal/root/dopravni-inzenyrstvi/intenzity-dopravy [cit. 2021-04-05]. 